Vol. 82, 2009

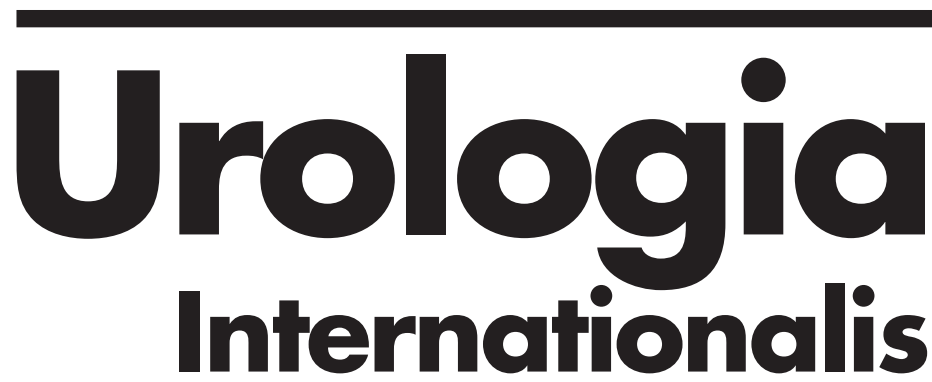

Founded 1955 by G. Peter A. Narath and Heinrich Heusser

Successors: G. Mayor (1968-1987); D. Hauri (1988-2005)

\section{Editors}

M.P. Wirth, Dresden

M. Porena, Perugia

O.W. Hakenberg, Rostock

D. Castro-Diaz,

Santa Cruz de Tenerife

\section{Editorial Committee}

R. Ackermann, Düsseldorf

Y. Aso, Tokyo

Ph. Jaeger, Uxbridge

G. Jakse, Aachen

R. Mundy, London

J. Nordling, Herlev

P. Rigatti, Milano

H. Rübben, Essen

F. Schröder, Rotterdam

G. Watson, Eastbourne

W. Weidner, Giessen

\title{
Board of Reviewing Editors
}

P. Albers, Düsseldorf

G.L. Andriole, St. Louis

W. Artibani, Verona

G. Baretton, Dresden

P. Bassi, Padova

P. Caione, Roma

P. Fornara, Halle

B. Frea, Novara

J.P. Gearhart, Baltimore

W. Horninger, Innsbruck

G. Janetschek, Salzburg
M.M. Karram, Cincinnati

J.N. Krieger, Seattle

M. Lazzeri, Firenze

V.R. Marshall, Adelaide

E. Montanari, Milano

G. Morgia, Messina

G. Nicita, Firenze

R.T.D. Oliver, London

S. Siracusano, Trieste

N. Sofikitis, Ioannina

F. Verrey, Zürich 
S. Karger

Medical and Scientific Publishers

Basel $\cdot$ Freiburg $\cdot$ Paris $\bullet$ London •

New York $•$ Bangalore $\cdot$ Bangkok

Shanghai $\cdot$ Singapore $\cdot$ Tokyo $\cdot$ Sydney
Disclaimer

The statements, opinions and data contained in this publication are solely those of the individual authors and contributors and not of the publisher and the editor(s). The appearance of advertisements in the journal is not a warranty, endorsement or approval of the products or services advertised or of thei effectiveness, quality or safety. The publisher and the editor(s) disclaim responsibility for any injury to persons or property resulting from any ideas, methods, instructions or products referred to in the content or advertisements.

Drug Dosage

The authors and the publisher have exerted every effort to ensure that drug selection and dosage set forth in this text are in accord with current recommendations and practice at the time of publication. However, in view of ongoing research, changes in government regulations, and the constant flow of information relating to drug therapy and drug reactions, the reader is urged to check the package insert for each drug for any change in indications and dosage and for added warnings and precautions. This is particularly important when the recommended agent is a new and/or infrequently employed drug.
All rights reserved.

No part of this publication may be translated into other languages, reproduced or utilized in any form or by any means, electronic or mechanical, including photocopying, recording, microcopying, or by any information storage and retrieval system, without permission in writing from the publisher or, in the case of photocopying, direct payment of a specified fee to the Copyright Clearance Center (see 'General Information')

(c) Copyright 2009 by S. Karger AG,

P.O. Box, CH-4009 Basel (Switzerland)

Printed in Switzerland

on acid-free and non-aging paper (ISO 9706) by

Reinhardt Druck, Basel

\section{KARGER}




\section{Urologia

No. 1

Review

1 Chemotherapy in Patients with Penile Carcinoma Protzel, C.; Hakenberg, O.W. (Rostock)

Original Papers

8 Bicycle Saddle Pressure: Effects of Trunk Position and Saddle Design on Healthy Subjects

Carpes, F.P. (Porto Alegre); Dagnese, F.; Kleinpaul, J.F.; de Assis Martins, E.; Bolli Mota, C. (Santa Maria)

12 Transrectal Ultrasound as Diagnostic Tool for the Detection of Local Recurrence following Cystectomy and Urinary Diversion Simon, J.; Bartsch, G., Jr.; Rinnab, L.; Hautmann, R.E.; Volkmer, B.G. (Ulm)

17 Health-Related Quality of Life after Radical Prostatectomy and Low-Dose-Rate Brachytherapy for Localized Prostate Cancer

Wyler, S.F.; Engeler, D.S.; Seelentag, W.; Ries, G.; Schmid, H.-P. (St. Gallen)

24 Nephron-Sparing Surgery: The Effect of Surface Cooling and Temporary Renal Artery Occlusion on Renal Function Bakirtas, H.; Eroglu, M.; Naldoken, S.; Akbulut, Z.; Tekdogan, U.Y. (Ankara)

28 Our 21-Year Experience with the Thiersch-Duplay Technique following Surgical Correction of Penoscrotal Transposition Sunay, M.; Emir, L.; Karabulut, A.; Erol, D. (Ankara) [Editorial Comment by J.P. Gearhart, Baltimore, Md.]

32 Prostatitis-Like Symptoms: Diagnosis and Management in a Malaysian Primary Care Population

Lee, S.W.H.; Liong, M.L.; Yuen, K.H.; Leong, W.S.; Khan, N.; Cheah, P.Y. (Penang); Krieger, J.N. (Seattle, Wash.)

38 Hydronephrosis Promotes Expression of Hypoxia-Inducible Factor $1 \alpha$

Stravodimos, K.G.; Koritsiadis, G.; Lazaris, A.C.; Agrogiannis, G.; Koutalellis, G.; Constantinides, C.; Patsouris, E.; Kapetanakis, T.; Zervas, A. (Athens)

43 Alterations of Urine TGF- $\beta 1$ and bFGF following Bladder Outlet Obstruction: A Predictor for Detrusor Contractibility? Shi, B.; Zhu, Y. (Jinan); Laudon, V. (Hartford, Conn.); Ran, L.; Liu, Y.; Xu, Z. (Jinan)

48 Local Factors Compared with Systemic Factors in the Formation of Bladder Uric Acid Stones

Li, W.-M.; Chou, Y.-H.; Li, C.-C.; Liu, C.-C.; Huang, S.-P.; Wu, W.-J.; Huang, C.-H. (Kaohsiung)

53 Statistical Evaluation of Hemodynamic Effects of Regular Use of Sildenafil on the Human Corpora Cavernosa

Natali, A.; Bartolini, M.; Lucarini, S.; Vignolini, G.; Nelli, F.; Menchi, I. (Florence)

61 Transurethral Incision of the Bladder Neck Using KTP in the Treatment of Bladder Neck Obstruction in Women Fu, Q.; Xu, Y.-M. (Shanghai)
65 Cystic Nephroma, Cystic Partially Differentiated Nephroblastoma and Cystic Wilms' Tumor in Children: A Spectrum with Therapeutic Dilemmas van den Hoek, J.; de Krijger, R.; van de Ven, K.; Lequin, M.; van den Heuvel-Eibrink, M.M. (Rotterdam)

71 Uroflow Findings in Older Boys with Tubularized Incised-Plate Urethroplasty

Tuygun, C.; Bakirtas, H.; Gucuk, A.; Cakici, H.; Imamoglu, A. (Ankara)

77 Influence of High Bladder Pressure on Vesicoureteral Reflux and Its Resolution

Acar, B.F.; Arıkan, F.I.; Germiyanoğlu, C.; Dallar, Y. (Ankara)

81 Long-Term Efficiency of Skin Stretching and a Topical Corticoid Cream Application for Unretractable Foreskin and Phimosis in Prepubertal Boys

Ghysel, C.; Vander Eeckt, K.; Bogaert, G.A. (Leuven)

89 Development of Sertoli Cells during Mini-Puberty in Normal and Cryptorchid Testes

Zivkovic, D.; Hadziselimovic, F. (Liestal)

92 Low Transscrotal Orchidopexy Is a Safe and Effective Approach for Undescended Testes Distal to the External Inguinal Ring

Takahashi, M. (Tokushima); Kurokawa, Y. (Mima); Nakanishi, R.; Koizumi, T.; Yamaguchi, K.; Taue, R.; Kishimoto, T.; Kanayama, H. (Tokushima)

97 Properties in Penetrating Capsula of Transurethral Plasmakinetic Resection: Comparison with Transurethral Resection of the Prostate in an ex vivo Study Qu, L.; Wang, X.; Wang, H.; Huang, X. (Guangzhou)

101 In vitro and in vivo Effects of Vardenafil (a PDE-5 Inhibitor) on Corpus Cavernosal Smooth Muscle Relaxation in Diabetic Rabbits

Lau, D.H.W. (London); Mumtaz, F.H. (Enfield); Mikhailidis, D.P. Thompson, C.S. (London)

108 Study of 5-Aza-CdR on Transcription Regulation of RASSF1A Gene in the BIU87 Cell Line

Liu, X.; Dai, X.; Wu, B. (Shenyang)

Case Reports

113 Prostate Cancer-Producing Granulocyte Colony-Stimulating Factor

Matsuoka, Y.; Arai, G.; Okada, Y.; Aida, J. (Tokyo)

116 Collagen Graft Interposition in Vesicovaginal Fistula Treatment Robles, J.E.; Saiz, A.; Rioja, J.; Brugarolas, X.; Berian, J.M. (Pamplona)

119 A New Modified Renal Vein Anastomosis in Unilateral Dual Renal Transplantation

Wang, D. (Guangzhou); Li, H. (Guangzhou/Zhuhai); Deng, S.; Chen, W.; Chen, L. (Guangzhou)

122 Mucoepidermoid Lung Tumor Appearing as an Abscess on the Scrotum

Szendrői, A.; Majoros, A.; Székely, E.; Szücs, M.; Romics, I. (Budapest)

\section{KARGER}

Fax +41613061234 E-Mail karger@karger.ch www.karger.com

\section{(C) 2009 S. Karger AG, Base}

Access to full text and tables of contents, including tentative ones for forthcoming issues: www.karger.com/uin_issues 
No. 2

Review

125 An Evidence-Based Perspective to the Medical Treatment of Male Infertility: A Short Review

Ghanem, H. (Cairo); Shamloul, R. (Cairo/Kingston, Ont.)

Original Papers

130 Comparison of HoLEP and TURP in Terms of Efficacy in the Early Postoperative Period and Perioperative Morbidity Mavuduru, R.M.; Mandal, A.K.; Singh, S.K.; Acharya, N.; Agarwal, M.; Garg, S.; Kumar, S. (Chandigarh)

136 Usefulness of Naftopidil for Dysuria in Benign Prostatic Hyperplasia and Its Optimal Dose - Comparison between 75 and $50 \mathbf{~ m g}$ Oh-oka, H. (Kobe)

143 Toll-Free Telephone Medical Information on Nocturnal Enuresis: The First Italian Experience over a Two-Year Period Ferrara, P.; Nicoletti, A.; Emmanuele, V. (Rome); Chiozza, M.L. (Padua); Aceto, G. (Bari); Del Gado, R. (Naples); Caione, P. (Rome)

147 Distribution of High Chromogranin A Serum Levels in Patients with Nonmetastatic and Metastatic Prostate Adenocarcinoma Sciarra, A.; Di Silverio, F.; Autran, A.M.; Salciccia, S.; Gentilucci, A.; Alfarone, A.; Gentile, V. (Rome)

152 Lessons from 52 Patients with Leydig Cell Tumor of the Testis: The GUONE (North-Eastern Uro-Oncological Group, Italy) Experience

Di Tonno, F. (Venice); Tavolini, I.M. (Venice/Padua); Belmonte, P.; Bertoldin, R.; Cossaro, E. (Venice); Curti, P. (Verona); D’Incà, G. (Belluno); Fandella, A. (Treviso); Guaitoli, P. (Gorizia); Guazzieri, S. (Belluno); Mazzariol, C. (Venice)

158 Epididymoorchitis due to Brucella melitensis: Review of 19 Patients

Gul, H.C. (Ankara); Akyol, I.; Sen, B.; Adayener, C.; Haholu, A. (Istanbul)

162 Decrease of Renal Function due to Warm Ischemia after Laparoscopic Partial Nephrectomy: Evaluation Using 99mTc-DMSA Renal Scintigraphy

Tachikake, T. (Hiroshima); Shigeta, M. (Kure); Mita, K.; Marukawa, K. Usui, T.; Ito, K. (Hiroshima)

166 Adjunctive Medical Therapy with an $\alpha$-1A-Specific Blocker after Shock Wave Lithotripsy of Lower Ureteral Stones Wang, C.-J.; Huang, S.-W.; Chang, C.-H. (Chiayi)

170 Vasectomy Reversal: A Seven-Year Experience Busato, Jr., W.F.S. (Itajai)

175 Penile Vascular Impairment in Erectile Dysfunction Patients with Metabolic Syndrome: Penile Doppler Ultrasound Findings

Demir, O.; Demir, T.; Kefi, A.; Secil, M.; Comlekci, A.; Yesil, S.; Esen, A.A. (Izmir)

179 Outcome of End-to-End Urethroplasty: Single-Center Experience

Gupta, N.P.; Mishra, S.; Dogra, P.N.; Hemal, A.K.; Seth, A.; Kumar, R. (New Delhi)

183 Repair of Distal Hypospadias and Preputioplasty in One Operation. Risks and Advantages

Papouis, G.; Kaselas, C.; Skoumis, K.; Kaselas, V. (Thessaloniki)

187 Sclerotherapy of the Pampiniform Plexus with Modified Marmar Technique in Children and Adolescents Carmignani, L.; Casellato, S.; Galasso, G.; Bozzini, G.; Spinelli, M.; Dell'Agnola, C.A.; Rocco, F. (Milan)

191 Distal Urethral Polypropylene Sling Surgical Management for Urodynamic Stress Incontinence in Korean Women Lee, J.H. (Seoul); Kim, K.H. (Incheon); Lee, H.W.; Kim, K.H.; Choi, J.S (Seoul); Yoon, S.J. (Incheon); Han, J.S.; Lee, K.W. (Seoul)
196 Health-Related Quality of Life in Patients with Hormone Refractory Prostate Cancer Receiving Gefitinib Curigliano, G.; Spitaleri, G.; De Cobelli, O.; Scardino, E.; Sbanotto, A.; de Braud, F. (Milan)

203 Serum Adipocytokine Levels in Prostate Cancer Patients Arisan, E.D. (Bakirkoy-İstanbul); Arisan, S.; Atis, G.; Palavan-Unsal, N.; Ergenekon, E. (Sisli-İstanbul)

209 Construction of Urothelium-Specific Recombinant Adenovirus and Its Inhibition in Bladder Cancer Cell He, X.-D.; Wang, Z.-P. (Lanzhou); Wei, H.-Y.; Zhou, Q. (Chengdu); Wang, D.-G.; Tian, J.-Q.; Fu, S.-J. (Lanzhou); Rodriguez, R. (Baltimore, Md.)

214 Protein Kinase $C$ Is Involved in Arsenic Trioxide-Induced Apoptosis and Inhibition of Proliferation in Human Bladder Cancer Cells

Wang, Y.; An, R.; Dong, X.; Pan, S. (Harbin); Duan, G. (Auckland); Sun, X. (Harbin/Auckland)

222 A Twelve-Year Experience with Adrenal Cortical Carcinoma in a Single Institution: Long-Term Survival after Surgical Treatment and Transcatheter Arterial Embolization Soga, H.; Takenaka, A.; Ooba, T.; Nakano, Y.; Miyake, H.; Takeda, M.; Tanaka, K.; Hara, I.; Fujisawa, M. (Kobe)

227 Arsenic Methylation Capability, Myeloperoxidase and Sulfotransferase Genetic Polymorphisms, and the Stage and Grade of Urothelial Carcinoma

Huang, S.K.; Chiu, A.W.-H. (Tainan/Taipei); Pu, Y.-S.; Huang, Y.-K.; Chung, C.-J.; Tsai, H.-J. (Taipei); Yang, M.-H. (Hsinchu); Chen, C.-J. Hsueh, Y.-M. (Taipei)

Case Reports

235 Retroperitoneal Laparoscopic Uretero-Pyelostomy for Symptomatic Yo-Yo Reflux Khan, M.; Qadri, S.J.F.; Bhat, A.H.; Khan, N. (Srinagar)

238 Urinary Retention, Erectile Dysfunction and Meningitis due to Sacral Herpes Zoster: A Case Report and Review of the Literature Erol, B.; Avci, A.; Eken, C.; Ozgok, Y. (Zonguldak)

242 Female Hydrocele: The Cyst of Nuck Caviezel, A.; Montet, X.; Schwartz, J.; Egger, J.-F.; Iselin C.E. (Geneva)

246 Toxic Dermatolysis, Tissue Necrosis and Impaired Wound Healing due to Sunitinib Treatment Leading to Forefoot Amputation

Feyerabend, S.; Schilling, D.; Wicke, C.; Stenzl, A. (Tübingen)

No. 3

Review

249 Impact of Surgical and Medical Castration on Serum Testosterone Level in Prostate Cancer Patients Novara, G.; Galfano, A.; Secco, S.; Ficarra, V.; Artibani, W. (Padua)

Original Papers

256 Impact of Obesity on Surgical Outcomes following Open Radical Prostatectomy

van Roermund, J.G.H.; van Basten, J.-P.A.; Kiemeney, L.A.; Karthaus, H.F.M.; Witjes, J.A. (Nijmegen)

262 Is Only Perianal Anesthesia with Lidocaine-Prilocaine Cream Sufficient to Decrease the Pain during Transrectal Ultrasound-Guided Prostate Biopsy? A Prospective Randomized Study Kandirali, E.; Ulukaradag, E.; Uysal, B.; Serin, E.; Semercioz, A.; Metin, A. (Bolu) 
266 Do Changes in a High Serum Prostate-Specific Antigen Level and the Free/Total Prostate-Specific Antigen Ratio after Antibiotic Treatment Rule Out Biopsy and the Suspicion of Cancer?

Dirim, A.; Tekin, M.I.; Koyluoglu, E.; Oguzulgen, A.I.; Peskircioglu, L.; Ozkardes, H. (Ankara)

270 Comparison of 6- and 12-Core Prostate Biopsy in Taiwanese Men: Impact of Total Prostate-Specific Antigen, ProstateSpecific Antigen Density and Prostate Volume on Prostate Cancer Detection

Chiang, I-N.; Chang, S.-J.; Pu, Y.-S.; Huang, K.-H.; Yu, H.-J.; Huang, C.-Y. (Taipei)

276 Comparison of Three Analgesic Treatment Protocols for Pain Management during Extracorporeal Shock Wave Lithotripsy Eryıldırım, B.; Kuyumcuoğlu, U.; Tarhan, F.; Faydacı, G.; Uruç, F. (Istanbul)

280 Free PSA/Total PSA Ratio Increases the Detection Rate of Prostate Cancer in Twelve-Core Biopsy

Yokomizo, Y.; Miyoshi, Y.; Nakaigawa, N.; Makiyama, K.; Ogawa, T.; Yao, M.; Kubota, Y.; Uemura, H. (Yokohama)

286 Role of AgNOR Count and Its Correlation with Serum PSA Levels in Prostatic Lesions

Goel, T.; Garg, S. (Manipal)

291 Significance of Serum Calcitonin Gene-Related Peptide Levels in Prostate Cancer Patients Receiving Hormonal Therapy Suzuki, K.; Kobayashi, Y.; Morita, T. (Tochigi)

296 A Lower Risk of Dying from Urological Cancer in Down Syndrome: Clue for Cancer Protecting Genes on Chromosome 21

Satgé, D. (Tulle); Sasco, A.J. (Bordeaux); Day, S. (San Francisco, Calif.); Culine, S. (Montpellier)

301 Three-Dimensional Computed Tomography of the Orthotopic Ileal Neo-Bladder Reconstruction: Normal and Abnormal Findings

Sassi, C.; Santilli, L.; Concetti, S.; Schiavina, R.; Amadori, E.; Severini, E.; Martorana, G.; Battista, G. (Bologna)

306 The Risk Factor for Urethral Recurrence after Radical Cystectomy in Patients with Transitional Cell Carcinoma of the Bladder

Cho, K.S.; Seo, J.W.; Park, S.J.; Lee, Y.H.; Choi, Y.D.; Cho, N.H.; Yang, S.C.; Hong, S.J. (Seoul)

312 Aurora-A/STK-15 Is Differentially Expressed in the Micropapillary Variant of Bladder Cancer Compérat, E.; Roupret, M.; Conort, P.; Chartier-Kastler, E.; Bitker, M.-O.; Richard, F.; Capron, F.; Haertig, A.; Cussenot, O.; Camparo, P. (Paris)

318 Cigarette Smoking and Drinking Water Source: Correlation with Clinical Features and Pathology of Superficial Bladder Carcinoma

Serretta, V. (Palermo); Altieri, V. (Napoli); Morgia, G. (Messina); Allegro, R. Ruggirello, A. (Palermo); Di Lallo, A. (Campobasso); Carrieri, G. (Foggia); Melloni, D. (Palermo); Members of the foundation 'Gruppo Studi Tumori Urologici (GSTU)'

324 Multifocality Incidence and Accompanying Clinicopathological Factors in Renal Cell Carcinoma Sargin, S.Y.; Ekmekcioglu, O.; Arpali, E.; Altinel, M.; Voyvoda, B. (Ankara)

330 Laparoscopic Radical Nephrectomy: A Journey from T1 to Very Large T2 Tumors

Srivastava, A.; Gupta, M.; Singh, P.; Dubey, D.; Mandhani, A.; Kapoor, R.; Kumar, A. (Lucknow)

335 Comparison of Open Nephroureterectomy and Open Conservative Management of Upper Urinary Tract Transitional Cell Carcinoma

Dragicevic, D.; Djokic, M.; Pekmezovic, T.; Vuksanovic, A.; Micic, S.; Hadzi-Djokic, J.; Tulic, C.; Milenkovic, D.; Pljesa-Ercegovac, M.; Simic, T. (Belgrade)
341 Ureteroscopic Laser Lithotripsy versus Ballistic Lithotripsy for Treatment of Ureteric Stones: A Prospective Comparative Study

Garg, S.; Mandal, A.K.; Singh, S.K.; Naveen, A.; Ravimohan, M.;

Aggarwal, M.; Mete, U.K.; Santosh, K. (Chandigarh)

346 Tubeless Percutaneous Nephrolithotomy for Geriatric Patients Jou, Y.; Lin, C.; Shen, C.; Cheng, M.; Chen, P. (Chiayi)

350 Evaluation of Urolithiasis: A Link between Stone Formation and Diabetes Mellitus?

Zimmerer, T.; Weiss, C.; Hammes, H.P.; Braun, C. (Mannheim); Hesse, A. (Bonn); Alken, P.; Knoll, T. (Mannheim)

356 Use of the Stone Cone for Prevention of Calculus Retropulsion during Holmium:YAG Laser Lithotripsy: Case Series and Review of the Literature

Eisner, B.H.; Dretler, S.P. (Boston, Mass.)

361 Fascial Interposition Technique for Vasectomy: Is It Justified? Shakeri, S.; Aminsharifi, A.R.; Khalafi, M. (Shiraz)

Case Reports

365 Rectourethral Fistula following LDR Brachytherapy Borchers, H.; Pinkawa, M.; Donner, A.; Wolter, T.P.; Pallua, N.; Eble, M.J.; Jakse, G. (Aachen)

367 Early-Stage Sarcomatoid Renal Cell Carcinoma: Multidetector CT Findings

Giannakis, D.; Tsili, A.C.; Zioga, A.; Tsampoulas, K.; Sofikitis, N. (Ioannina)

370 Erosion of an Intrauterine Contraceptive Device through the Bladder Wall Causing Calculus: Management and Review of the Literature

Mustafa, M. (Osmaniye)

Letter to the Editor

372 Dartos Flap in Snodgrass Hypospadias Repair Bakan, V. (Kahramanmaras)

369 Erratum

No. 4

Review

373 Testicular Varicocele: An Overview

Mohammed, A.; Chinegwundoh, F. (Ayr)

Original Papers

380 Expression of DLC-1 in Clear Cell Renal Cell Carcinoma: Prognostic Significance for Progression and Metastasis Zhang, T.; Zheng, J.; Liu, C.; Lu, Y. (Shanghai)

388 Impact of Thymidine Phosphorylase-Expressing Macrophages for Surgical Margin in Partial Nephrectomy

Liu, H.; Takayama, T.; Ogawa, H.; Kai, F.; Sugiyama, T.; Aoki, T.; Harada, M.; Otsuka, A.; Furuse, H.; Kurita, Y.; Mugiya, S.; Ushiyama, T.; Ozono, S. (Hamamatsu)

$394 \mathrm{ProACT}^{\mathrm{TM}}$ for Stress Urinary Incontinence after Radical Prostatectomy Martens, F.M.J.; Lampe, M.I.; Heesakkers, J.P.F.A. (Nijmegen)

399 Is Circumcision a Modified Ritual of Castration? Mordeniz, C.; Verit, A. (Sanliurfa)

404 Our Experience with Genitourinary Fistulae Kumar, A.; Goyal, N.K.; Das, S.K.; Trivedi, S.; Dwivedi, U.S.; Singh, P.B. (Varanasi)

411 Robotic Repair of Complex Vesicouterine Fistula with and without Hysterectomy

Hemal, A.K.; Sharma, N.; Mukherjee, S. (New Delhi) 
416 Bulbocavernosus Muscle Flap for the Repair of Vesicovaginal Fistula. Anatomic Study and Clinical Results

Fu, Q.; Bian, W.; Lv, J. (Jinan)

420 Clinical Management of Bladder Dysfunction Caused by Sexual Abuse

Pannek, J.; Einig, E.-M.; Einig, W. (Herne)

426 Vacuum-Assisted Closure for the Treatment of Fournier's Gangrene

Cuccia, G.; Mucciardi, G.; Morgia, G.; Stagno d’Alcontres, F.; Galì, A.; Cotrufo, S.; Romeo, M.; Magno, C. (Messina)

432 Influence of Body Mass Index on Operability, Morbidity and Disease Outcome following Radical Cystectomy

Maurer, T.; Maurer, J.; Retz, M.; Paul, R.; Zantl, N.; Gschwend, J.E.; Treiber, U. (München)

440 Tubeless and Stentless Percutaneous Nephrolithotomy in Patients Requiring Supracostal Access

Gonen, M.; Cicek, T. (Konya); Ozkardes, H. (Ankara)

444 Histomorphological Differences of Spermatic Cords regarding Subinguinal versus Inguinal Levels: A Cadaveric Study

Tuccar, E.; Yaman, O.; Erdemli, E.; Zeyrek, T.; Esmer, A.F.; Kilic, O. (Ankara); Avunduk, M.C. (Konya)

448 Paratesticular Sarcomas in Brazil

Korkes, F.; Castro, M.G.; Romero, F.R.; Godoy, G.; Amary, M.F.; Fernandes, R.C.; Perez, M.D. (São Paulo)

453 Is There Any Additional Benefit of Venous Diameter and Retrograde Flow Volume as Measured by Ultrasonography to the Diagnosis of Suspected Low-Grade Varicoceles? Bakirtas, H.; Cakan, M.; Tuygun, C.; Soylu, S.O.; Ersoy, H. (Ankara)
459 Role of Calcium in the Aggregation of Particles Coated by Urinary Macromolecules

Baumann, J.M.; Affolter, B.; Caprez, U.; Clivaz, C.; von Arx, U. (Biel)

464 Prophylaxis of Experimentally Induced Calcium Oxalate Nephrolithiasis in Rats by Zhulingtang, a Traditional Chinese Herbal Formula

Tsai, C.-H.; Pan, T.-C.; Lai, M.-T.; Lee, S.-C.; Chen, M.-L.; Jheng, J.-R.; Chen, W.-C. (Taichung)

Case Reports

472 Painful Leg: A Very Unusual Presentation of Renal Cell Carcinoma. Case Report and Review of the Literature Gözen, A.S.; Canda, A.E.; Naser, M.; Stock, C.; Rassweiler, J.; Teber, D. (Heilbronn)

477 Sebaceous Carcinoma of the Penis

Ornellas, A.A.; Frota, R.; Lopes da Silva, L.F.; Dauster, B.; Quirino, R.; de Santos Schwindt, A.B.; Pereira, M.R. (Rio de Janeiro)

481 Epididymo-Orchitis due to Brucellosis: Not Only to Be Considered in Endemic Areas . Two Cases for the Price of Three Patients

Moens, A.A.; Vlaspolder, F.; Verlind, J.; Sepers, J.M.; Stam, F. (Alkmaar)

Letter to the Editor

484 Designing a Novel Double-J Stent to Facilitate the Expulsion of Urinary Stones

Amiri, M. (Ilam); Hajihasani, M.; Gharibzadeh, S. (Tehran)

485 Author Index Vol. 82, 2009

488 Subject Index Vol. 82, 2009 